\title{
Bacterial contamination of boar semen and its relationship to sperm quality preserved in commercial extender containing gentamicin sulfate
}

\author{
D. Gączarzewicz ${ }^{1}$,J. Udała ${ }^{1}$, M. Piasecka², B. Błaszczyk ${ }^{1}$, T. Stankiewicz ${ }^{1}$ \\ ${ }^{1}$ Department of Animal Reproduction, Biotechnology, and Environmental Hygiene, \\ Faculty of Biotechnology and Animal Breeding, West Pomeranian University of Technology, \\ Doktora Judyma 6, 71-466 Szczecin, Poland \\ ${ }^{2}$ Department of Histology and Developmental Biology, Pomeranian Medical University, \\ Żołnierska 48, 71-210 Szczecin, Poland
}

\begin{abstract}
This study was designed to determine the degree and type of bacterial contamination in boar semen (79 ejaculates from Large White and Landrace boars) and its consequences for sperm quality during storage (27 extended semen samples, $16^{\circ} \mathrm{C}$ for five days) under practical conditions of artificial insemination (AI). The results revealed the presence of aerobic bacteria in $99 \%$ of the ejaculates (from 80 to $370 \times 10^{6}$ colony-forming units $/ \mathrm{mL}$ ). Most of the ejaculates contained two or three bacterial contaminants, while the Staphylococcus, Streptococcus, and Pseudomonas bacterial genera were most frequently isolated. Also detected were Enterobacter spp., Bacillus spp., Proteus spp., Escherichia coli, $P$. fluorescens, and $P$. aeruginosa. In general, the growth of certain bacterial types isolated prior to semen processing (Enterobacter spp., E. coli, $P$. fluorescens, and P. aeruginosa) was not discovered on different days of storage, but fluctuations (with a tendency towards increases) were found in the frequencies of Bacillus spp., Pseudomonas spp., and Staphylococcus spp. isolates up to the end of storage. Semen preserved for five days exhibited decreases in sperm motility and increases in the average number of total aerobic bacteria; this was associated with sperm agglutination, plasma membrane disruption, and acrosome damage. We inferred that, due to the different degrees and types of bacterial contaminants in the boar ejaculates, the inhibitory activity of some antimicrobial agents used in swine extenders (such as gentamicin sulfate) may be limited. Because such agents can contribute to the overgrowth of certain aerobic bacteria and a reduction in the quality of stored semen, procedures with high standards of hygiene and microbiological control should be used when processing boar semen.
\end{abstract}

Key words: boar spermatozoa, liquid storage, semen quality, bacterial contamination

Correspondence to: D. Gączarzewicz, e-mail: dariusz.gaczarzewicz@zut.edu.pl 


\section{Introduction}

Ejaculates collected from healthy boars are usually contaminated with bacteria, containing up to $10^{9}$ microorganisms/mL (Althouse et al. 2000). Most microorganisms detected in boar ejaculates are considered (to some extent) nonpathogenic (Althouse et al. 2000, Maes et al. 2008, Morrell and Wallgren 2014), and they seem to have little effect on fecundity under natural mating conditions (Speck et al. 2014), as the female reproductive tract has developed its own defense mechanisms to cope with bacteria from the semen (Dalin et al. 2004, Morrell and Wallgren 2011). However, when such semen is used in AI, there is a possibility that the bacteria will grow and multiply in the extended semen. AI doses with bacterial overgrowth that are deposited in the female genital tract could contribute to an increase in postinsemination vulvar discharges or a regular return to estrus, as well as to embryonic or fetal death, endometritis, systemic infections, or disease in inseminated sows and gilts (Dalin et al. 2004, Maes et al. 2008, Morrell and Wallgren 2011, Goldberg et al. 2013). Moreover, high levels of bacterial contamination have unfavorable effects on the sperm cells in extended semen (Althouse et al. 2008, Kuster and Althouse 2016). If bacterial contamination is left uncontrolled, the end result is economic loss for porcine studs (Althouse et al. 2000, Althouse and Lu 2005, Baracaldo and Ward 2008, Maroto Martín et al. 2010). To avoid these problems, proper hygienic procedures should be respected during the collection and laboratory processing of semen, especially given that it has recently been emphasized that the antimicrobials usually used in porcine semen to prevent the growth of contaminating bacteria are of limited effectiveness (Althouse and Lu 2005, Goldberg et al. 2013, Speck et al. 2014, Schulze et al. 2015, Kuster and Althouse 2016).

This study was accordingly designed to determine the degree and type of bacterial contamination of ejaculated semen samples in fertile boars and its consequences for sperm quality (e.g., motility and integrity of sperm membranes) during storage in commercial extender for five days at $16^{\circ} \mathrm{C}$.

\section{Materials and Methods}

\section{Animals, semen collection, and storage}

Seventy-nine ejaculates collected from 26 Large White (39 ejaculates) and 30 Landrace (40 ejaculates) boars with proven fertility from the local AI center, and with ages ranging from 1.5 to 2.5 years, were used in this study.
Between February and April, sperm-rich ejaculate fractions were collected by the gloved hand technique into disposable filtering bags enclosed in insulated plastic thermos cups preheated to $37^{\circ} \mathrm{C}$. Prior to each semen collection, the animals were thoroughly cleaned and led to a properly cleaned collection room. Immediately after collection, the native semen (NS) with more than $200 \times 10^{6}$ sperm $/ \mathrm{mL}$ that displayed a minimum of $70 \%$ progressive motility and $80 \%$ morphologically normal spermatozoa was isothermically diluted in $\mathrm{X}$-cell ${ }^{\circledR}$ extender (containing a single antibiotic, gentamicin sulfate; IMV, France) so that each $90 \mathrm{~mL}$ AI dose stored in closed plastic bags contained $3.0 \times 10^{6} \mathrm{sperm} / \mathrm{mL}$. After $2 \mathrm{~h}$ holding time at room temperature, the $\mathrm{AI}$ doses were cooled to $16^{\circ} \mathrm{C}$ (D0: the day of collection) and then stored for five days (D1-D5) with gentle agitation twice daily. Randomly selected samples of stored semen $(n=27)$ were analyzed as described below, with newly opened AI doses being used at each time point. The semen samples were prewarmed to $37^{\circ} \mathrm{C}$, before proceeding to sperm quality analysis.

\section{Semen evaluation}

The percentage of sperm cells with progressive motility was assessed using a phase-contrast microscope at $\times 400$ magnification $(\mathrm{BX} 41$; Olympus Optical Co., Japan) and a heating stage $\left(37^{\circ} \mathrm{C}\right)$. Under these conditions, the extent of agglutination of the sperm cells was scored as 0 (no agglutination), 1 (less than $10 \%$ of sperm agglutinated), 2 (10\%-25\% agglutinated) and 3 (more than $25 \%$ agglutinated). Aggregation the clumping of nonmoving sperm cells was not considered. Sperm and acrosome morphology were evaluated according to methods and classification described by Gączarzewicz et al. (2010). In each sperm sample, two hundred spermatozoa were evaluated under oil immersion $(\times 1000)$ using a bright field microscope (BX 41). The $\mathrm{pH}$ of the semen samples was measured using a two-point calibrated (pH 6.0 and 8.0; Poch, Poland) pH-meter (CP-315M, Elmetron; electrode type ERH-13-6, Hydromet, Poland). The measurement of aspartate aminotransferase (AAT; EC 2.6.1.1) activity was used to determine the changes in sperm plasma membrane integrity during storage (Gączarzewicz et al., 2015). Enzyme activity was assessed by the kinetic method according to the manufacturer's protocol (A6461, Alpha Diagnostics, Poland). The results were expressed as AAT activity per $10^{9}$ spermatozoa (mU/10 ${ }^{9}$ spermatozoa). Sperm concentration was determined by manual counting on a standard Bürker hemocytometer. 


\section{Bacteriological evaluation}

All semen samples (79 of native semen and 135 of stored semen) were analyzed for the presence of microbiological contamination by plating on the following media: defibrinated sheep blood agar (5\% v/v; Oxoid, UK), MacConkey agar (Oxoid), Mueller-Hinton agar (Oxoid), Sabouraud agar (Oxoid, UK), Pseudomonas agar (MP Biomedicals, US), Chapman medium (Oxoid, UK), and nitrate reduction medium. The media were prepared according to the manufacturer's instructions and the plates were incubated in aerobic conditions at $37^{\circ} \mathrm{C}$. The phenotypic properties of isolated bacteria were investigated using different methods, depending on type; the identification process was based on the use of the Gram staining and Analytical Profile Index systems (API 10S, API Staph and API 20NE; bioMérieux, France).

The quantitative degree of bacterial contamination in the native semen was determined for each isolated strain, while in the stored semen this was monitored by designating the total number of aerobic bacteria. A ten-fold serial dilution of the semen sample (in $0.1 \mathrm{~mol} / \mathrm{L}$ PBS) was prepared for bacteria counting. From each dilution, $0.5 \mathrm{~mL}$ was plated onto plates and incubated at $37^{\circ} \mathrm{C}$ under aerobic conditions for $24 \mathrm{~h}$ and $48 \mathrm{~h}$. Concentration was expressed in terms of colony forming units per $\mathrm{mL}(\mathrm{CFU} / \mathrm{mL})$, which was calculated as the average of the number of colonies on three plates. Based on the concentration counts for the stored semen samples, the number of sperm was determined for use in calculating the aerobic ratio, taking into account the 100:1 or 1:1 criterion as the threshold.

\section{Statistical analysis}

Statistical analysis was performed using the Statistica software package (version 10.0; StatSoft Incorporation, Tulsa OK, USA). The data were examined using the Shapiro-Wilk $W$-test for the possibility that they significantly deviated from a normal distribution. The nonparametric Mann-Whitney $U$-test was used to compare the results obtained for both boar breeds. The Friedman ANOVA test was applied to determine the influence of storage time on the semen quality parameters. Comparisons between storage time points were performed using Wilcoxon's rank-sum test. Differences were considered significant if the probability of their occurring by chance was less than $5 \%(\mathrm{p}<0.05)$. Results are expressed as means \pm standard error of the mean (SEM); for bacteria isolated from native semen, the median, minimum, and maximum values are also noted. Correlations between the measured sperm quality parameters were calculated using Spearman's rank correlation coefficient $\left(\mathrm{r}_{\mathrm{s}}\right)$ with $\mathrm{p}<0.05$ as the significance level.

\section{Results}

\section{Quality and bacterial contamination of native semen}

In this study, no statistically significant interracial differences between the examined features of semen quality $(p>0.05)$ were recognized. Generally, the average volume of the sperm-rich fraction of the ejaculates for both breeds of boars was $202.41 \pm 5.63 \mathrm{~mL}$ at a concentration level of $451.58 \times 10^{6} \pm 3.37 \times 10^{6}$ of sperm $/ \mathrm{mL}$. Progressive motility was noted in $78.04 \%$ of the sperm, ranging in different ejaculates from $70 \%$ to $85 \%$. Normal morphological structure and acrosome structure were recognized in, respectively, 87.37 $\pm 0.69 \%$ and $94.22 \pm 0.26 \%$ of the sperm. The $\mathrm{pH}$ had an average of 7.50 and ranged from 7.04 to 7.84 .

The microbial results indicated that, of the 79 ejaculates, a single bacterial contaminant was present in $9 \%(7 / 79)$ of the ejaculates; $23 \%(18 / 79)$ and $42 \%$ (33/79) contained two and three bacterial types, respectively; 19 specimens contained 4-6 contaminants. Table 1 lists the types of bacteria isolated from the semen, with counts for each type and the percentage of ejaculates contaminated with each. Seventy-eight out of 79 ejaculates were positive for aerobic bacteria, whose numbers ranged from 80 to $370 \times 10^{6} \mathrm{CFU} / \mathrm{mL}$. Six species of rod-shaped Gram-negative bacteria belonging to the Enterobacteriaceae and Pseudomonadaceae families (respectively, Enterobacter spp., E. coli, Proteus spp., and Pseudomonas spp.; $P$. fluorescens and $P$. aeruginosa) and three species of Gram-positive bacteria (Bacillus spp., Staphylococcus spp., and Streptococcus spp.) were isolated. The bacteria genera Staphylococcus and Streptococcus, and an unidentified bacterium of the Pseudomonas genus were the most frequent contaminants. There were no strictly anaerobic microorganisms in any of the samples, and all proved negative for mycological examination.

\section{Bacteriological status and quality of the semen during storage}

For most bacteria detected in the native semen, the number of samples from which it could be isolated after dilution either directly decreased (Bacillus spp., Staphylococcus spp., Streptococcus spp., $P$. fluorescens and $P$. aeruginosa) or did not increase (Enterobacter 
Table 1. Microorganisms $(\mathrm{CFU} / \mathrm{mL})$ isolated from boar semen samples $(\mathrm{n}=79)$ and the proportion of ejaculates with the identified bacteria.

\begin{tabular}{lccc}
\hline \multicolumn{1}{c}{ Bacteria } & Mean \pm SEM & $\begin{array}{c}\text { Median } \\
\text { Minimum-Maximum }\end{array}$ & Percentage of isolates (n) \\
\hline Total aerobic bacteria & $14.52 \times 10^{6} \pm 5.84 \times 10^{6}$ & $\begin{array}{c}7.70 \times 10^{3} \\
80.00-370.00 \times 10^{6}\end{array}$ & $98.73(78)$ \\
\hline Bacillus spp. & $36.07 \times 10^{6} \pm 17.09 \times 10^{6}$ & $\begin{array}{c}90.00 \times 10^{3} \\
10.00-220.00 \times 10^{6}\end{array}$ & $21.52(17)$ \\
\hline Enterobacter spp. & $2.80 \times 10^{3} \pm 1.38 \times 10^{3}$ & $\begin{array}{c}210.00 \\
20.00-27.00 \times 10^{3}\end{array}$ & $29.11(23)$ \\
\hline Escherichia coli & $0.75 \times 10^{6} \pm 0.60 \times 10^{6}$ & $\begin{array}{c}670.00 \\
10.00-10.00 \times 10^{6}\end{array}$ & $21.52(17)$ \\
\hline Proteus spp. & $313.33 \pm 122.03$ & $\begin{array}{c}260.00 \\
10.00-730.00\end{array}$ & $7.60(6)$ \\
\hline Pseudomonas aeruginosa & $3.37 \times 10^{3} \pm 1.13 \times 10^{3}$ & $\begin{array}{l}3.60 \times 10^{3} \\
1.00 \times 10^{3}-5.30 \times 10^{3} \\
7.10 \times 10^{3}\end{array}$ & $5.06(4)$ \\
\hline Pseudomonas fluorescens & $0.47 \times 10^{6} \pm 0.24 \times 10^{6}$ & $140.00-2.60 \times 10^{6}$ & $16.46(13)$ \\
\hline Pseudomonas spp. & $4.46 \times 10^{6} \pm 3.25 \times 10^{6}$ & $\begin{array}{c}700.00 \\
4.00-100.00 \times 10^{6}\end{array}$ & $\begin{array}{c}590.00 \\
14.00-1.00 \times 10^{6}\end{array}$ \\
\hline Staphylococcus spp. & $21.59 \times 10^{3} \pm 18.51 \times 10^{3}$ & $\begin{array}{l}360.00 \\
10.00-100.00 \times 10^{3}\end{array}$ & $54.43(43)$ \\
\hline Streptococcus spp. & $5.91 \times 10^{3} \pm 2.53 \times 10^{3}$ & $68.35(54)$
\end{tabular}

Note: average values were calculated using only semen samples containing the bacteria.

Table 2. Percentage of semen samples with specific bacteria identified in undiluted semen (NS), after dilution with X-cell ${ }^{\circledR}$ extender (D0: day of collection), and during storage for 5 days (D1-D5) at $16^{\circ} \mathrm{C}(\mathrm{n}=27$ semen samples).

\begin{tabular}{|c|c|c|c|c|c|c|c|}
\hline Specificity in semen & NS & D0 & D1 & D2 & D3 & D4 & D5 \\
\hline Total aerobic bacteria & $96.30(26)$ & $62.96(17)$ & $88.89(24)$ & $100.00(27)$ & $92.59(25)$ & $92.59(25)$ & $100.00(27)$ \\
\hline Bacillus spp. & $55.56(15)$ & $22.22(6)$ & $37.04(10)$ & $88.89(24)$ & $48.15(13)$ & $48.15(13)$ & $70.37(19)$ \\
\hline Enterobacter spp. & $25.93(7)$ & ng & $37.04(10)$ & $3.70(1)$ & $7.41(2)$ & ng & ng \\
\hline Escherichia coli & $25.93(7)$ & ng & $7.41(2)$ & $7.41(2)$ & $3.70(1)$ & ng & ng \\
\hline Pseudomonas aeruginosa & $14.81(4)$ & $7.41(2)$ & $25.93(7)$ & $29.63(8)$ & ng & ng & ng \\
\hline Pseudomonas fluorescens & $48.15(13)$ & $11.11(3)$ & ng & ng & ng & ng & ng \\
\hline Pseudomonas spp. & $22.22(6)$ & $29.63(8)$ & $44.44(12)$ & $48.15(13)$ & $70.37(19)$ & $55.56(15)$ & $51.85(14)$ \\
\hline Staphylococcus spp. & $51.85(14)$ & $3.70(1)$ & $14.81(4)$ & $11.11(3)$ & $25.93(7)$ & $29.63(8)$ & $37.04(10)$ \\
\hline Streptococcus spp. & $48.15(13)$ & $3.70(1)$ & $18.52(5)$ & $14.81(4)$ & $29.63(8)$ & ng & $7.41(2)$ \\
\hline $\begin{array}{l}\text { Ratio of sperm to aerobic } \\
\text { bacteria at least } 100: 1\end{array}$ & $51.90(14)$ & $14.81(4)$ & $55.56(15)$ & $11.11(3)$ & $51.85(14)$ & $37.04(10)$ & $22.22(6)$ \\
\hline $\begin{array}{l}\text { Ratio of sperm to aerobic } \\
\text { bacteria lower than } 100: 1\end{array}$ & $44.40(12)$ & 48.15 (13) & $33.33(9)$ & 88.89 (24) & 40.74 (11) & $55.56(15)$ & 77.78 (21) \\
\hline $\begin{array}{l}\text { Ratio of sperm to aerobic } \\
\text { bacteria lower than } 1: 1\end{array}$ & $\mathrm{nf}$ & $18.52(5)$ & $7.41(2)$ & $25.93(7)$ & $11.11(3)$ & 40.74 (11) & 37.04 (10) \\
\hline
\end{tabular}

Note: ng: no growth (at the given time, the bacteria did not show any growth in the semen samples); nf: not found.

spp., E. coli). Only in case of the unidentified Pseudomonas bacteria did an increase in the number of isolates occur-both after dilution as well as during storage (in the period D0-D3). Apart from Bacillus spp., this bacterium was the most frequently isolated during storage: on D5 it was present in 52\% of samples, while Bacillus spp. was present in $70 \%$. In turn, $P$. fluorescens was not found from D1 onwards, $P$. aeruginosa was not found from D3 onwards, and Enterobacter spp. and E. coli were not found from D4 

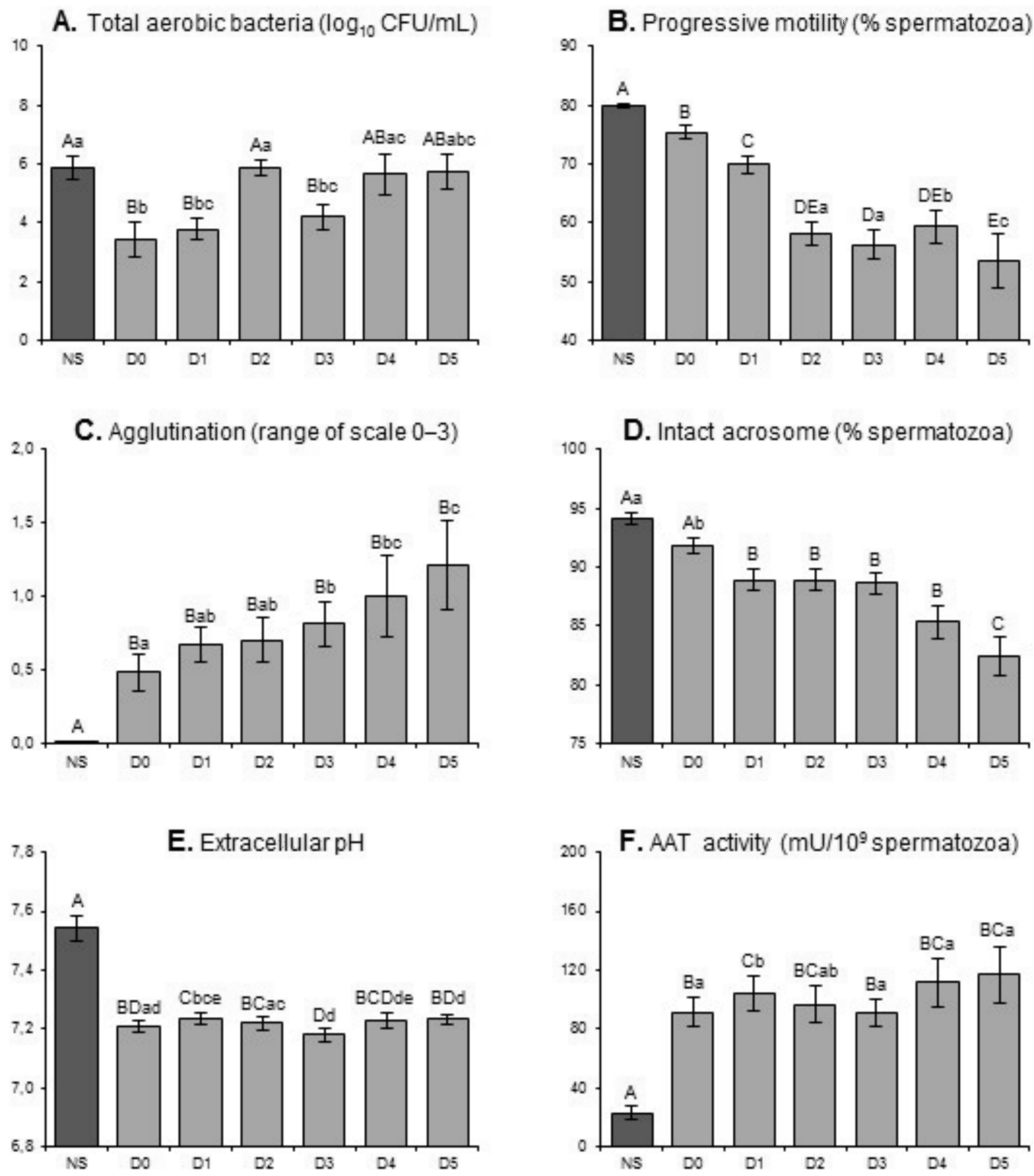

Figs. 1A-F. Changes in level of contamination with total aerobic bacteria and in sperm-quality parameters in undiluted semen (NS), after dilution with X-cell ${ }^{\circledR}$ extender (D0: day of collection), and during storage for 5 days (D1-D5) at $16^{\circ} \mathrm{C}(\mathrm{n}=27$ semen samples). Different letters indicate significant differences between the semen stored at various stages of maintenance, lowercase (a-e) at $\mathrm{p}<0.05$ and uppercase $(\mathrm{A}-\mathrm{E})$ at $\mathrm{p}<0.01$. AAT: aspartate aminotransferase. Bars represent means \pm SEMs. Wilcoxon's rank-sum test was used for multiple comparisons.

onwards in any of the of semen samples. Moreover, over the course of the study, an increase was seen in the number of semen samples with sperm : aerobic bacteria ratios of less than 100:1 and less than 1:1 (Table 2).
Both the dilution of the ejaculates $(\mathrm{p}<0.01)$ and the duration of storage $(\mathrm{p}<0.05)$ have a significant impact on the total number of aerobic bacteria in semen. After dilution (on D0), the average number of CFU per $\mathrm{mL}$ of semen decreased from $724 \times 10^{3}$ to $2.7 \times 10^{3}$. 


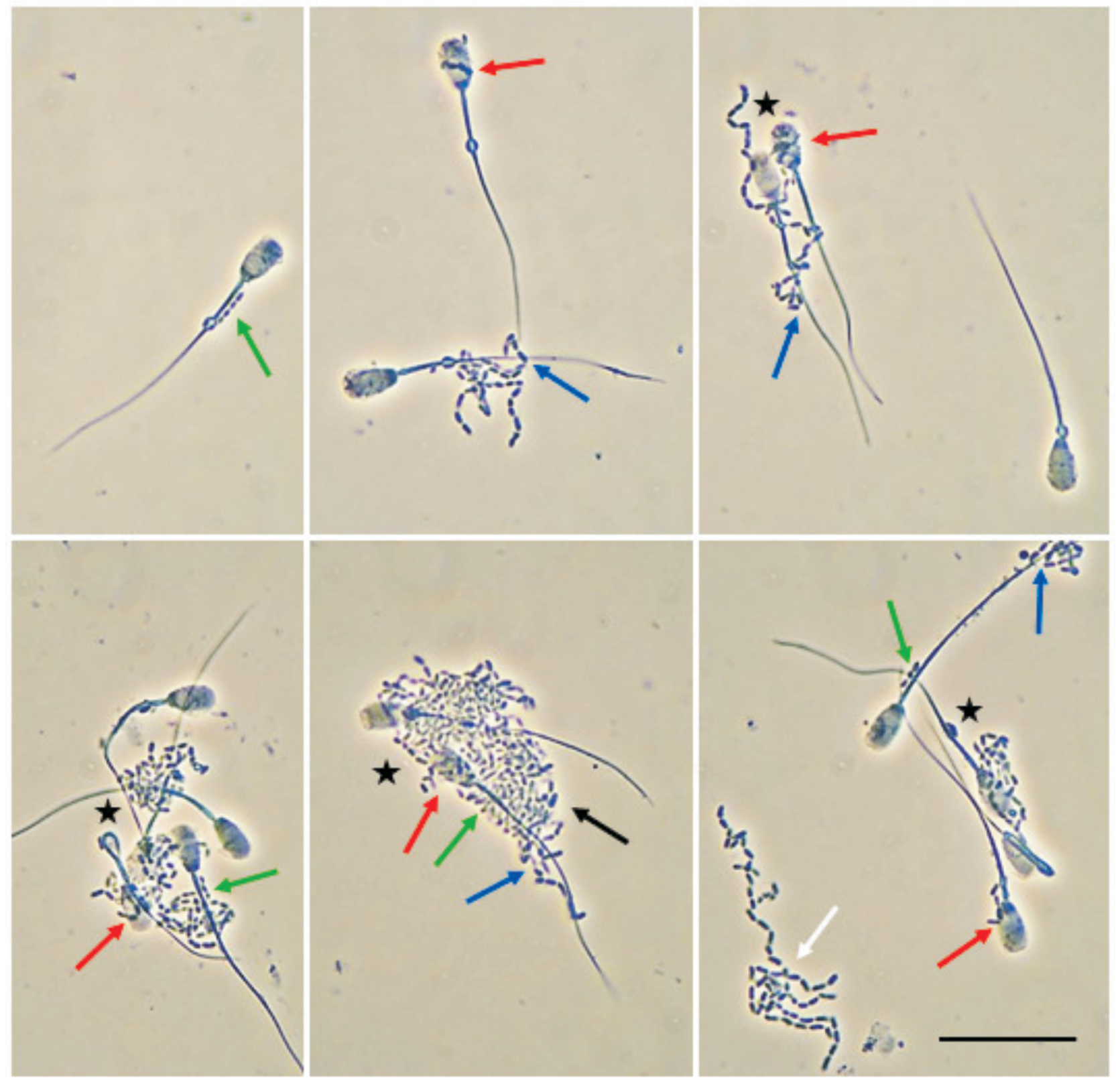

Fig. 2. Representative micrographs of bacteriospermia in extended boar semen. Rod-shaped bacteria are present both separately (white arrow) and among the spermatozoa (black arrow); they adhere to the sperm surface at the level of the head (red arrows), midpiece (green arrows), and tail (blue arrows); the bacterial contamination favors sperm agglutination (asterisk). Phase-contrast microscope; Scale bar: $20 \mu \mathrm{m}$.

Significant fluctuations $(\mathrm{p}<0.05)$ in the growth of the aerobic bacterial populations were found during semen storage (Fig. 1A). On each day of storage, large variabilities were seen in the extent of semen contamination with aerobic bacteria in particular samples, ranging from 0 to $1.2 \times 10^{9} \mathrm{CFU} / \mathrm{mL}$.

The dilution of the semen had an influence on all parameters and storage time had a significant impact on the motility, agglutination, and acrosome integrity of the spermatozoa, as well as on AAT activity in the extracellular environment. The percentage of spermatozoa with progressive motility, which was 79.8 $\pm 0.4 \%$ in the fresh semen, dropped significantly after dilution to $75.4 \pm 1.0 \%$, and over the subsequent days of storage fell to $53.6 \pm 4.5 \%$ (D5; Fig. 1B). During storage, a gradual increase in sperm agglutination was observed. In comparison to the initial period of storage $(\mathrm{D} 0)$, a significant increase $(\mathrm{p}<0.05)$ in agglutination level was observed from D3 onwards. Differences $(p<0.05)$ were also found between the period D0-D3 (days in which less than $10 \%$ of the sperm was agglutinated) and D5 (Fig. 1C; Fig. 2). After dilution, the percentage of sperm with undamaged acrosomes decreased by about $2 \%$ to $91.8 \pm 0.7 \%(\mathrm{p}<0.05)$, while 
after five days of storage it had decreased to 82.4 $\pm 1.6 \%$ (Fig. 1D). Diluting the ejaculates led to a decrease $(\mathrm{p}<0.01)$ in the $\mathrm{pH}$ from $7.54 \pm 0.04$ to 7.21 \pm 0.02 and an increase in AAT activity from $23.0 \pm 4.0$ $\mathrm{mU} / 10^{9}$ spermatozoa to $91.5 \pm 10.3 \mathrm{mU} / 10^{9}$ spermatozoa. During the entire period of storage, the average pH ranged from 7.18 to 7.24 (Fig. 1E), while the minimum values of $\mathrm{pH}$ observed for some samples ranged from 6.85 to 7.09 (data not shown). The average AAT activity after five days of storage increased to 116.7 $\pm 19.6 \mathrm{mU} / 10^{9}$ spermatozoa (Fig. $1 \mathrm{~F}$ ), while the maximum values of AAT activity in the period D0-D5 ranged from approximately 216 to $297 \mathrm{mU} / 10^{9}$ spermatozoa (data not shown). During the study, weak though statistically significant $(\mathrm{p}<0.05)$ correlations were observed between the number of CFU on one hand and sperm agglutination $\left(\mathrm{r}_{\mathrm{s}}=0.19\right)$, percentage of sperm with undamaged acrosomes $\left(\mathrm{r}_{\mathrm{s}}=-0.18\right), \mathrm{pH}$ $\left(r_{\mathrm{s}}=0.21\right)$, and AAT activity $\left(r_{\mathrm{s}}=-0.23\right)$, on the other.

\section{Discussion}

\section{Bacterial contamination of boar ejaculates}

Almost all ejaculates (99\%) included in this study were contaminated with various bacteria types previously reported in boar semen (Althouse et al. 2000, Althouse and Lu 2005, Maroto Martín et al. 2010, Morrell and Wallgren 2011, Bresciani et al. 2014, Schulze et al. 2015). Our research largely confirms the general view that Gram-negative bacteria, especially from the Enterobacteriaceae family, are most prevalent in boar semen (Althouse and Lu 2005, Okazaki et al. 2010, Úbeda et al. 2013, Kuster and Althouse 2016). We also isolated six species of rod-shaped Gram-negative bacteria belonging to the Enterobacteriaceae and Pseudomonadaceae families and three species of Gram-positive bacteria (Table 1). These results are consistent with those of other authors, compiled by Maroto Martín et al. (2010), who conclude that, of at least 25 different bacteria genera identified in boar semen, the species Pseudomonas, Staphylococcus, Proteus, and E. coli, occur most frequently.

The bacterial contaminants isolated by us may have various origins in both animal (e.g. E. coli, Enterobacter spp., and Staphylococcus spp.) and nonanimal (e.g. Pseudomonas, Bacillus, and other species) sources (Althouse and Lu 2005, Baracaldo and Ward 2008). Recently, the importance has been explained of many specific factors associated with the age and hygiene of boars and with the technique and hygiene of semen collection, all of which can significantly affect semen contamination by aerobic and coliform bac- teria (Goldberg et al. 2013). The collection of ejaculates under less hygienic conditions leads to an increase in contamination to above the median value of $220 \mathrm{CFU} / \mathrm{mL}$ (Goldberg et al. 2013). In the present research, the level of contamination with aerobic bacteria was higher (median $7.7 \times 10^{3} \mathrm{CFU} / \mathrm{mL}$ ), but considerable variation was noted between the bacteria considered separately and together. These results may thus be explained by faults in semen collection and by differences between boars in terms of the native properties of their semen. Our results are nevertheless consistent with the data reported in the literature that point to a total aerobic bacteria count in boar ejaculates averaging from $10^{3}$ to $10^{5} \mathrm{CFU} / \mathrm{mL}$ (range: $0-10^{6}$ ) (Schulze et al. 2015), and with higher levels up to $10^{9}$ bacteria/mL (Althouse et al. 2000, Baracaldo and Ward 2008).

\section{Response to storage of bacterial growth dynamics and sperm quality}

The present research, consistent with several previous studies of AI practice (Althouse 2008, Maroto Martín et al. 2010, Úbeda et al. 2013, Bresciani et al. 2014), shows that the occurrence of bacteria in extended semen is very common in everyday practice and may be associated with limited control of bacterial growth during storage of semen. Many of the common bacterial genera found in boar semen are resistant to aminoglycosides, which are among the most common antibiotics found in semen extenders (Althouse et al. 2000, Althouse and Lu 2005, Althouse 2008, Maes et al. 2008). Our results are based on bacterial survival and proliferation (isolate frequency and changes in the level of total aerobic bacteria) and point to a selective pattern of bacterial growth in response to the bacteriostatic action of the single antibiotic in the extender. It seems that during semen storage, the gentamicin sulfate employed especially limits the expansion of Gram-negative bacteria (except for the unidentified strain of Pseudomonas), while the growth of Gram-positive contaminants is not so strongly inhibited; this results in an increase in the isolate frequency of these species. These changes in the structure of the microbiological profile are clearly visible in the final period of semen storage (D4 and D5; Table 2) and may result from the properties of gentamicin, which more effectively protects against Gram-negative bacteria but otherwise has a relatively narrow spectrum of activity (Althouse and $\mathrm{Lu}$ 2005). As shown in recent research, all of the bacteria (Schulze et al. 2015), or at least a significant proportion of them (Bresciani et al. 2014), isolated from boar semen in European areas may be resistant to gentamicin. In 
our study, we found an overall increase in the level of total aerobic bacteria over the five-day test period, with peaks in the growth on D2 and D4-D5 (Fig. 1A). It thus cannot be ruled out that bacterial growth was not efficiently inhibited (or eliminated) by gentamicin. On the other hand, the commercial extender used in the study should satisfy the conditions determined by the actual legal norms which require the addition to the boar semen of effective antibacterial treatment products. These norms were laid down in the Regulation of the Ministry for Agriculture and Rural Development (Journal of Laws of the Republic of Poland of 2013, item 1016) in accordance with Directive 90/429/EEC, with later amendments.

Considering the changes observed by us in the microbiological profile, it can further be suggested that some bacterial populations have the ability to rapidly develop in certain samples of extended semen. These could contribute to increases in the number of total aerobic bacteria at different storage times. These findings seem consistent with the dynamics of bacterial growth in semen extenders proposed by some authors (see Althouse 2008, Althouse et al. 2008). In general, we explain our results concerning the degree of microbiological contamination by suggesting that the increase in total aerobic bacteria on D2 represents the stationary stage (resting phase), which was preceded by the periods of adaptation and then rapid growth (lag and log phases, respectively; from D0 to about D2). The change at D3-a significant decrease in total aerobic bacteria-then results from the decline or death phase of certain bacterial types which, in the next two days (D4-D5), began to proliferate again in the subsequent microbial generations. These fluctuations may depend on many factors (including antimicrobial effectiveness, extender type, temperature and time of incubation, and bacterial genera) and their interactions (Vyt et al. 2004, Althouse et al. 2008, Kuster and Althouse 2016). It should be stressed that our results clearly confirm that some bacterial genera undergo a 48 -h adaptation stage to the extender and temperature environment, as has been indicated by other authors (Althouse et al. 2008, Sepúlveda et al. 2014). This may be related to the higher quality of the semen in the initial period of storage. According to Úbeda et al. (2013), a short time for interaction between bacteria and sperm may lead to underestimation of the negative impact of some bacteria on sperm in AI. In turn, other authors have stated that the presence of bacteria in AI samples does not have any significant impact on either the farrowing rate or the total number of births (Reicks and Levis 2008).

In our study, the 5-day storage period resulted in a reduction in sperm quality (Fig. 1). We associate these changes with the degree of aerobic bacteria contamination, even though it is difficult to demonstrate this clearly; the correlation may be indicated by several facts: (i) we observed the occurrence of statistically significant correlations between the number of aerobic bacteria and semen quality parameters; (ii) we noted an increase in the frequency of semen samples with a significant number of aerobic bacteria, as well as a doubling in the number of doses with a very high degree of contamination (Table 2); (iii) we observed an intensification in direct interaction between bacteria and sperm related to bacterial adhesion to the surface of sperm, which was accompanied by intensified agglutination, particularly in the final period of storage (Fig. 2). Our results are thus in agreement with the numerous studies that indicate that bacterial contamination can affect the quality and longevity of boar semen during storage, and that high levels of bacterial contamination can lead to undesired effects in insemination doses and fertility results (Althouse et al. 2000, Maroto Martín et al. 2010, Bussalleu et al. 2011, Sa et al. 2014), especially when the proportion of sperm to bacteria is approximately $1: 1$, or for some types of bacteria, 100:1 (Althouse 2008, Althouse et al. 2008, Kuster and Althouse 2016). The negative impact of bacteria on boar semen stored at temperatures of $15-17^{\circ} \mathrm{C}$ (after a little more than $24-48 \mathrm{~h}$ from inoculation) was indicated mainly by experimental studies that showed high concentrations of some bacteria species (Bussalleu et al. 2011, Sepúlveda et al. 2013, 2014, Prieto-Martínez et al. 2014).

Importantly, as some reports have suggested, the antibiotics (such as gentamicin) added to extenders can themselves contribute to harmful alterations of sperm function in extended semen (Aurich and Spergser 2007). Moreover, these effects may be also associated with bacteriolysis, due to their antibiotic action and the release of soluble spermatotoxic factors from bacteria (Okazaki et al. 2010). It is rather clear that, in doses with bacterial overgrowth stored for a long time, such spermicidal mechanisms may play an even greater role. It is possible that they may contribute to the data obtained in the present study, although our results on the deleterious direct effects of bacteria on spermatozoa were firmly supported by prominent tight adhesion of bacteria to the sperm surface and by sperm agglutination in the presence of bacteria.

\section{Concluding remarks}

The observations made in this study provide evidence of the occurrence of different degrees and types of bacterial contamination in raw boar ejaculates. In stored semen, most likely because of the limited activ- 
ity of antimicrobial agents in the extended semen, the levels of some bacterial strains can increase considerably and, with time in storage, the bacteria can come to directly influence sperm cells, deteriorating semen quality. It therefore seems that the use of a semen extender possessing bacteriostatic components that are effective against the bacterial strains found in boar studs may be crucial in maintaining boar sperm function, and that bacterial contamination should be considered an important parameter in the quality control of semen used for AI.

\section{References}

Althouse GC (2008) Sanitary procedures for the production of extended semen. Reprod Domest Anim 43 (Suppl. 2): 374-378.

Althouse GC, Kuster CE, Clark SG, Weisiger RM (2000) Field investigations of bacterial contaminants and their effects on extended porcine semen. Theriogenology 53: 1167-1176.

Althouse GC, Lu KG (2005) Bacteriospermia in extended porcine semen. Theriogenology 63: 573-584.

Althouse GC, Pierdon MS, Lu KG (2008) Thermotemporal dynamics of contaminant bacteria and antimicrobials in extended porcine semen. Theriogenology 70: 1317-1323.

Aurich C, Spergser J (2007) Influence of bacteria and gentamicin on cooled-stored stallion spermatozoa. Theriogenology 67: 912-918.

Baracaldo M, Ward J (2008) Quality control of extended boar semen. In: Murphy JM, de Lange CF (ed) Proceedings of the London Swine Conference - Facing the Now Reality. 1-2 April 2008, London, Ontario, pp 195-206.

Bresciani C, Cabassi CS, Morini G, Taddei S, Bettini R, Bigliardi E, Di Ianni F, Sabbioni A, Parmigiani E (2014) Boar semen bacterial contamination in Italy and antibiotic efficacy in a modified extender. Ital $\mathbf{J}$ Anim Sci 13: 83-87.

Bussalleu E, Yeste M, Sepúlveda L, Torner E, Pinart E, Bonet S (2011) Effects of different concentrations of enterotoxigenic and verotoxigenic $E$. coli on boar sperm quality. Anim Reprod Sci 127: 176-182.

Dalin AM, Kaeoket K, Persson E (2004) Immune cell infiltration of normal and impaired sow endometrium. Anim Reprod Sci 82-83: 401-413.

Gączarzewicz D, Piasecka M, Udała J, Błaszczyk B, Stankiewicz T, Laszczyńska M (2010) Plasma membrane changes during the liquid storage of boar spermatozoa: a comparison of methods. Acta Vet Hung 58: 105-116.

Gączarzewicz D, Udała J, Piasecka M, Błaszczyk B, Stankiewicz T (2015) Storage temperature of boar semen and its relationship to changes in sperm plasma membrane integrity, mitochondrial membrane potential, and oxidoreductive capability. Turk J Biol 39: 582-594.

Goldberg AM, Argenti LE, Faccin JE, Linck L, Santi M, Bernardi ML, Cardoso MR, Wentz I, Bortolozzo FP
(2013) Risk factors for bacterial contamination during boar semen collection. Res Vet Sci 95: 362-367.

Kuster CE, Althouse GC (2016) The impact of bacteriospermia on boar sperm storage and reproductive performance. Theriogenology 85: 21-26.

Maes D, Nauwynck H, Rijsselaere T, Mateusen B, Vyt P, de Kruif A, Van Soom A (2008) Diseases in swine transmitted by artificial insemination: an overview. Theriogenology 70: 1337-1345.

Maroto Martín LO, Muñoz EC, De Cupere F, Van Driessche E, Echemendia-Blanco D, Machado Rodríguez JM, Beeckmans S (2010) Bacterial contamination of boar semen affects the litter size. Anim Reprod Sci 120: 95-104.

Morrell JM, Wallgren M (2011) Removal of bacteria from boar ejaculates by Single Layer Centrifugation can reduce the use of antibiotics in semen extenders. Anim Reprod Sci 123: 64-69.

Morrell JM, Wallgren M (2014) Alternatives to antibiotics in semen extenders: a review. Pathogens 3: 934-946.

Okazaki T, Mihara T, Fujita Y, Yoshida S, Teshima H, Shimada M (2010) Polymyxin B neutralizes bacteria-released endotoxin and improves the quality of boar sperm during liquid storage and cryopreservation. Theriogenology 74: 1691-1700.

Prieto-Martínez N, Bussalleu E, Garcia-Bonavila E, Bonet S, Yeste M (2014) Effects of Enterobacter cloacae on boar sperm quality during liquid storage at $17^{\circ} \mathrm{C}$. Anim Reprod Sci 148: 72-82.

Reicks DL, Levis DG (2008) Fertility of semen used in commercial production and the impact of sperm numbers and bacterial counts. Theriogenology 70: 1377-1379.

Sa SJ, Choi SH, Kim HJ, Cho KH, Hong JK, Kim DW, Kim YH, Park JC, Chung KH (2014) Effect of different inoculation concentration of Escherichia coli on boar sperm quality and reproductive performance in sow. Reprod Dev Biol 38: 159-163.

Schulze M, Ammon C, Rudiger K, Jung M, Grobbel M (2015) Analysis of hygienic critical control points in boar semen production. Theriogenology 83: 430-437.

Sepúlveda L, Bussalleu E, Yeste M, Bonet S (2014) Effects of different concentrations of Pseudomonas aeruginosa on boar sperm quality. Anim Reprod Sci 150: 96-106.

Sepúlveda L, Bussalleu E, Yeste M, Torner E, Bonet $S$ (2013) How do different concentrations of Clostridium perfringens affect the quality of extended boar spermatozoa? Anim Reprod Sci 140: 83-91.

Speck S, Courtiol A, Junkes C, Dathe M, Müller K, Schulze M (2014) Cationic synthetic peptides: assessment of their antimicrobial potency in liquid preserved boar semen. PLoS One 9: e105949.

Úbeda JL, Ausejo R, Dahmani Y, Falceto MV, Usan A, Malo C, Perez-Martinez FC (2013) Adverse effects of members of the Enterobacteriaceae family on boar sperm quality. Theriogenology 80: 565-570.

Vyt P, Maes D, Dejonckheere E, Castryck F, Van Soom A (2004) Comparative study on five different commercial extenders for boar semen. Reprod Domest Anim 39: 8-12. 